\title{
Performance Analysis of Agricultural Sector Policy in Timor Tengah Utara Regency
}

\author{
DIAN FESTIANTO \\ Timor University, Jl. Km. 9 Jurusan Kupang, Kefamenanu, Timor Tengah Utara, Indonesia \\ email: d_festianto@yahoo.com
}

\begin{abstract}
This paper discusses the performance of agricultural sector policy in Timor Tengah Utara Regency focusing on the implementation of one of the village programs namely Desa Mandiri Cinta Petani (Sari Tani). This research uses qualitative descriptive method with case study approach to build alternative models of acceleration in agricultural sector policy. The Performance measured included inputs, processes, outputs, outcomes, and impacts. The research also applies Grindle concept because basically agricultural sector policy is inseparable from the influence of political interests of the actors involved in the implementation of the program. The result of the research shows that the superior program performance is not optimal due to the high tendency of intervention of political interests of the actors involved in the stages and quite systematic which ultimately impact on the low rate of return of revolving fund of farmer group which only reached $38 \%$. To improve the acceleration of agricultural sector development, it is necessary to establish an independent special team.
\end{abstract}

Keywords: Agricultural sector, Sari Tani Program, Timor Tengah Utara Regency

\section{Introduction}

The development of agricultural sector has a very strategic role, not only in improving the economy of rural communities, but also on the aspects of empowerment to realize socio-economic independence of rural communities. Desa Mandiri Cinta Petani (Sari Tani) program initiated by the Regent of Timor Tengah Utara or North Central Timor since 2011 to create the creative economy and food sovereignty in the village community is a bottom up policy by placing society as the subject of development. This research attemps to analyze the performance of Timor Tengah Utara Regent's superior program by using Grindle concept to explain the process of program implementation involving many actors of various interests. Thus, this study not only examines the procedural technical aspects, but also the socio-political aspects. Consideration, both aspects become the determining factor of successful implementation of agricultural sector development policy in Timor Tengah Utara Regency.
The underlying background of the initiative of Sari Tani program in Timor Tengah Utara (here after will be written TTU) Regency was a concern of Raymundus Sau Fernandes and his deputy Aloysius Kobes who elected in the period 2010-2015 and resumed in the second period of 2015-2020, who thought that similar programs already existed based on the villagers empowerment were less than optimal so that unable to overcome the poverty. The programs forementioned include The Presidential Instruction for Underdeveloped Village Program (IDT) and Integrated Development Center between Villages (PPTAD in Indonesian language) (Zulfida, et al., 2015: 307-318). In addition, Rice for the Poor Household (Raskin) program and Unconditional Cash Transfer (BLT in Indonesian language) program tend to spoil the community. These instant programs have an impact on the increasing level of community dependence on the state and the absence of new jobs. They have also damaged the mental and local wisdom values of the village community, such as the decrease of work ethic resulting in a high level of poverty

Received: 2018-07-02, Revisied: 2018-09-22, Accepted: 2019-05-29

Print ISSN: 0215-8175; Online ISSN: 2303-2499. DOI: http://dx.doi.org/10.29313/mimbar.v35i1.3830

Accredited $\mathbf{S 2}$ based on the decree No.10/E/KPT/2019 until 2024. Indexed by DOAJ, Sinta, Garuda, Crossreff, Dimensions 
in TTU Regency. The poverty occurs due to the lack of access to venture capital and minimal job creations.

Based on data from Central Bureau of Statistics (2012: 437), poor families in TTU regency has reached $55.54 \%$. The regency status as a poor area is further strengthened by The Presidential Regulation Number 131 of 2015 on Determination of Underdeveloped/ Disadvantaged Regions in 2015-2019. TTU regency is included in the category of disadvantaged regions. Chronic poverty in TTU regency has made poverty one of the strategic issues that require appropriate and systematic measures. Thus, this poverty issue is set forth in the Mid-term Development Plans of Timor Tengah Utara Regency 20102015 and 2015-2020.

Sari Tani program becomes an alternative offered by the regent in order to overcome poverty, especially in rural communities. This program aims to increase the independence and income of the community through the development of superior products in accordance with the available resources in TTU regency. In addition, the region's flagship program is the realization of the regent's promise during campaign in local elections and, politically, has received support from Regency Legislative Council (DPRD), so there is a certainty of budget support for it has been included in the regional budget. In accordance with the characteristics of problems faced in poverty alleviation, this program offers a convenience for people who need business capital, especially in the agricultural sector. Ideally, those programs will have impact on the creation of employment in the agricultural sector and the opportunity for the villager, especially those with low incomes.

A similar study on poverty alleviation is quite a matter of academic attention with its various approaches. Bekun and Tiza (2017: 4-9) in their research found that the implementation of Sari Tani program in TTU regency has not been optimal because the target community were unable to adopt the innovation offered in the form of entrepreneurship transformation. Thus, the attitude and behavior of the local community is still bound with customs that are firmly held by the community. Dima (2016: 171-176) in his research found that the implementation of Full-Employed Program (PKP) in TTU regency was constrained by limited resources owned by farmers who had not been able to adopt agricultural innovation, so that they did not get the rice aid.

While this study examines the performance of agricultural sector policy, especially the Sari Tani program, not only from the procedural technical aspects but also from political aspects. The assumption is that the success of a policy involving many actors is influenced by the policy content and the context of policy implementation. This political aspect is one of the advocates for the success of a policy in the formulation until the evaluation stage because a good program will not succeed without considering the sociopolitical aspects surrounding the policy.

All this time, agricultural sector policy studies tend to never consider the political aspects at all in measuring success or anticipation when there is a diversity of responses to the policy. As a result, when problems occur, there are no solutions; and the failure of a policy is always addressed to the target community. The problem is ultimately a policy problem because it is unresolved at each level of policy. For that purpose, this study aims to measure the performance of Sari Tani program using social and political perspective.

A review on agricultural sector policy in TTU regency is urgently considered as it contributes to policy studies and practically contributes to local government in the formulation of development policies which in line with the characteristics and capabilities of local communities.

\section{Research Methodology}

This study explains the agricultural sector policy in Timor Tengah Utara Regency with a focus on the performance of Sari Tani program. It is conducted with analytical descriptive approach with the aim at building a certain theory or pattern (Creswell, 2010: 25) based on the phenomenon occurs daily (Yin, 1981: 30), especially in the implementation of Sari Tani program which involving many stakeholders. This study concentrated on three sub-districts, namely Miomaffo Timur (East Miomaffo), Biboki Utara (North Biboki), and Insana Utara (North Insana) with the consideration that the three sub-districts have the most access to the allocation of Sari Tani program compared to others, in addition to the fact that these three sub-districts geographically represent the characteristics of Timor Tengah Utara regency, which are mountainous, plains, and coastal areas. However, related data in other districts are 
also shown to compare the success rate of the implementation of Sari Tani program in the three sub-districts. Primary data collection was conducted through in-depth interviews with tiered stakeholders directly related to the implementation of Sari Tani program. During the field research process, the researcher also collected secondary data in the form of public documents.

Criteria for measuring the performance of Sari Tani program include aspects of input, process, output, outcomes, and impacts that have adopted Mahmudi's (2010: 80) opinion. Too complement the analysis in a political perspective, this study uses the concept of Grindle (1980: 11) in explaining the Sari Tani program viewed from two aspects of policy content and policy implementation context.

Research data processing was carried out through data reduction stages, drawing conclusions, and verification. The researchers also used Triangulation method to improve internal validity. (Moleong, 2001:95).

\section{Result And Discussion \\ Performance Analysis of Sari Tani Program}

The budget allocated for the need of the distribution of Sari Tani funds, which is sourced from Regional Budget Income, is increasing every year. Based on data from the Dinas Pemberdayaan Masyarakat Desa (village community empowerment service), in 2012 budget year, the funds distributed to 24 villages amounted to Rp.7.200.000.000,00. In 2013, the budget allocation for the flagship program of the regent increased to Rp.10.800.000.000,00 which was channeled to 36 villages. Entering the third year (2014), the budgets were almost tripled at Rp. $30.300 .000 .000,00$ which channeled to 101 villages. Thus, the total fund of Sari Tani was Rp.48.300.000.000,00 that has been channeled to was 161 target villages, with the average amount of funds for each village of almost Rp.300.000.000,00. The fantastic budget increase in 2014 was inseparable from the political influence because in 2015 TTU regency held the election of regional heads. It is suspected to be one of the incumbent strategies to get support from the villagers by disbursing even greater assistance even though the rate of Sari Tani's refund for the first and second year in three sub-districts was relatively low $(55,7 \%$ in 2012 and $70,2 \%$ in 2013.

The amount of fund distributed to each village that reached Rp.300.000.000,00 was not entirely be given to farmer groups, but also used for other operational costs. This other operational cost was Rp.50.000.000,00, divided into two activity items: Rp.40.000.000,00 for operational cost of Implemented-Unit of Sari Tani Program (UPST) for 3 years and Rp.10.000.000,00 for UPST training costs. Those were taken to realize the development of district superior programs such as cows breeding and fattening pigs, while agricultural enterprises engage peanuts, corn, and local garlic of single cloves with the fund of Rp.250.000.000,00.

From the aspect of human resources, the implementation of Sari Tani program was not only involved the extension of the field of Agriculture Department, but also other actors in gradual manner. In this program, the Regent acts as a person in charge and Village Society Empowering Department as the coordinator at the district level where the regional organization involved, which include the Agriculture Department, Department of Animal Husbandry, Food Control Department, and BKP3 (Socialization and Implementation Unit) of TTU.

This flagship program is implemented with an output target of reducing the poor family within five years. The target output was progressively determined gradually; in 2010 the number of poor families was 36,225

Table 1

Total Loans, Returns, and Arrears of Sari Tani Funds in East Miomaffo Subdistrict, North Biboki, and North Insana Year 2012-2014

\begin{tabular}{crrr}
\hline Year & Loans (Rp) & Returns (Rp) & \multicolumn{1}{c}{ Arrears (Rp) } \\
\hline 2012 & 844.435 .800 & 374.215 .781 & 470.220 .019 \\
2013 & 832.273 .000 & 247.624 .000 & 584.649 .000 \\
2014 & 3.114 .793 .200 & 1.007 .014 .681 & 2.107 .778 .519 \\
Amount & 4.791 .502 .000 & 1.628 .854 .462 & 3.162 .647 .538 \\
\hline
\end{tabular}


households $(65,62 \%)$ and in 2015 the number of poor families dropped to 26,012 households $(47,12 \%)$. The percentage of poor families dropped by $3,7 \%$ per annum, resulting in a cumulative decline in poverty rates in TTU regency for five years by $18,53 \%$.

Based on table 1 , the distribution of Sari Tani funds given to East Miomaffo, North Biboki, and North Insana subdistrict during 2012-2014 was very volatile. Sari Tani fund was revolving and for farmer groups who get it obliged to manage the funds in accordance with the productive effort managed by each farmer group, so that in the following year they are able to return the funds to the local government. In 2012, the donation was Rp.844.435.800,00 with the rate of return for the year after of Rp.374.215.781,00. Thus, in the first year the distribution of aid had been in arrears of farmer groups in the three districts for the amount of Rp.470.220.019,00 or almost $55,68 \%$. The high severance of Sari Tani reimbursement was due to the failure of cow breeding business. The failure of cow breeding based on the farmer's recognition is due to uncertainty of climate change, resulting in the scarcity of animal feed stocks. As a result, the growth of cows became obstructed and in the following year could not be sold to the market. In 2013, the distribution of aid to the farmer groups decreased to Rp.832.273.000,00. This is due to the decrease in the number of farmer groups and the type of productive enterprises that require smaller capital such as local garlic of single cloves and pig fattening. However, the data obtained shows that the rolling return rate is only Rp.247.624.000,00. Based on informants recognition, the problem was due to the failure of farmer groups in managing their productive business. Consequently, on this stage of disbursement there was an arrear of Rp.584.649.000,00 or almost $70,2 \%$. This showed that the percentage of arrears in the second year was greater than that in the first year.

Furthermore, in 2014, the distribution of aid to farmer groups increased dramatically compared to 2013, which was Rp.3.114.793.200,00. The increase was due to the increasing number of businesses and number of farmer groups targeted by the regent's flagship program. However, just like two years earlier, the revolving return rate only reached Rp.1.007.014.681,00, whereas the arrears of target farming groups accumulated reached Rp.2.107.778.519,00 or $67,7 \%$.

Overall, the Sari Tani fund rolled over to the target group reached Rp.4.791.502.000,00 with a return rate of Rp.1.628.854.462,00 or only $34 \%$, while revolving fund in arrears at farmer group level is Rp.3.162.647.538,00 or $66 \%$.

Based on data recapitulation from the Village Society Developing Department, up to 2017, the budget allocation for the Sari Tani program reached Rp.33.979.367.111,00 given to 161 villages located in TTU regency with the interest of Rp.2.091.058.165,00, then the obligation to be returned by all farmer group was Rp.36.111.518.676,00.

However, until February 2017, the rate of return on principal and interest at farmer level was very low at Rp.13.678.956.150,00 or $38 \%$. Whereas, the arrears to be returned by farmer groups at the regency level reached Rp.22.395.314.762,00 or $62 \%$, but this figure was still smaller than the percentage of delinquency in three districts of $64 \%$, districtlevel data is presented in Table 2 .

Disparities between the aids that had been given and the obligation of returns were large enough for farmer groups, so that it is

Table 2

Number of Loan, Return and Arrears of Sari Tani Fund per Type of Business in Timur Tengah Utara Regency in 2017

\begin{tabular}{lrrr}
\hline $\begin{array}{c}\text { Type of } \\
\text { Business }\end{array}$ & Loan (Rp) & \multicolumn{1}{c}{ Return (Rp) } & \multicolumn{1}{c}{ Arrears (Rp) } \\
\hline Cow breeding & 27.843 .475 .265 & $11.851 .089 .246(42,6 \%)$ & $15.992 .915 .630(57,4 \%)$ \\
Fattening pigs & 7.718 .753 .340 & $1.525 .451 .185(21 \%)$ & $6.155 .524 .780(79 \%)$ \\
Peanuts & 97.316 .000 & $79.728 .250(82 \%)$ & $17.587 .750(18 \%)$ \\
Corns & 316.188 .071 & $166.034 .719(52,5 \%)$ & $150.153 .352(47,5 \%)$ \\
Local Garlic & 135.786 .000 & $56.652 .750(42 \%)$ & $79.133 .250(58 \%)$ \\
Amount & 36.111 .518 .676 & $13.678 .956 .150(38 \%)$ & $22.395 .314 .762(62 \%)$ \\
\hline
\end{tabular}


necessary to review the local government's claim that the Sari Tani program has had an impact on the rate of poverty reduction in rural areas. From field observation, especially at the farmer group level, the average level of those managing Sari Tani funds had difficulty returning the principal loan along with the interest. There were reasons of why they were having difficulty returning the fund. For farmer groups working on cows breeding and fattening pigs, the first reason was the death of their livestock due to a disease, in which the farmers were unable to cope with due to the lack of knowledge of it. In fact, the case of cows and pigs was not merely a farmer's fault. Based on the recognition of farmers and Sari Tani Implemented-Unit (UPST), the obstacles faced by farmers are less intensive, as well as field counselors, agricultural extension workers from both the Agriculture and Department of Animal Husbandry, and community recruits to assist farmers. The Community-Group Companion (PKM), in particular, recruited by Village Society Empowering Department only to provide assistance in the areas of financial management and reporting.

The second reason was, some farmer groups working on cow breeding and pigs fattening were unwilling to return assistance on the grounds that some of the funds they received were borrowed by village officers and promised to be returned. But in reality, those village officers were unwilling to return the money and abused their power to repress the farmers. As a consequence, the farmers were unable to get their money back from those officers and then took a form of resistance by not returning the funds as well.

The third reason farmers was due to poor farmer-level behavior and ineffective controls by field facilitators. The farmer's wrong doing of taking the under-price (not of good quality) cow breeding and pig fattening made local Animal Husbandry Department could not sell their livestock within a year. For example, the price of a quality cow can be sold within a year for Rp.4.000.000,00, and in the next year it can be sold at an average price of Rp.10.000.000,00 so that in one year they can get profit forRp.6.000.000,00. Included in this case as the actions of some farmers who had no responsibility in managing the aid for the cows and pigs and used them for their consumptions instead, especially for the interests of the indigenous or party; and when the field companion inquired about their cow or pig they just replied that their livestock had died from disease.

Attitudes and behaviors shown by farmers based on the evidence and recognition of farmers working on cow breeding and pig fattening were in line with secondary data obtained from the Village Society Empowering Department where they were having difficulty in revocating the fund. Recorded until February 2017 , the realization of the rate of return of the cow cattle business with its interest rate was only Rp.11.851.089.246,00 or $42,56 \%$, while the principal arrears with interest reached Rp.15.992.915.630,00 or $57,44 \%$. The more apprehensive was the farmer's level of pigs fattening business with its return rate of only $19,76 \%$ or Rp.1.525.451.185,00 and the arrears up to February 2017 of Rp.6.155.524.780,00 or $79,24 \%$.

Although most of the farmers have difficulty in the reimbursement of Sari Tani fund, there are farmer groups who managed to bring it back in time. Based on the data of the community group namely "Citra Membangun", they were able to manage their Rp.26.500.000,00 fund well for their peanut businesses and successfully paid off the fund in December 2016.

The interesting findings of the field were that some of the people who succeeded in returning the Sari Tani's assistance did not come from the productivity of Sari Tani program, but came from a business outside this flagship program. Such cases in monitoring and evaluation phase by Village Society Empowering Department were not considered as failure of the programs. Local governments only measure the success in terms of rate of return of assistance and never take into account the origin of the money used to return the aid. If the government continues to be permissive in such cases, it will be biased in determining the success of a program.

In addition to the arrears of returns on funds, the implementation process of Sari Tani program had also many problems, such as; 1) A duplicate of the same name in farming groups who had received assistance from other programs at the provincial level. This case was caused by the error at the village level in identifying the people who were eligible for the assistance from Sari Tani program. This demonstrates that the degree of coordination both vertically and horizontally among related institutions was less synergistic. 2) There was internal conflict between the village leader and the manager 
of UPST in the village of Haekto due to a misunderstanding regarding the disbursement of aid distribution to the farmer group and the operational costs of the UPST which the village leader was not willing to sign the receipt. It also suggests that each respective actor at the village level had not yet fully understood the tasks and functions of their responsibilities. 3) There is a misunderstanding between a community group companion and a district government in East Noemuti. This suggests that community-based partners have not mastered the reporting procedures in a gradual manner in accordance with their technical guidelines. They are obliged to coordinate with the subdistrict government as the extension of the hand of the regent who responsible for the Sari Tani program. In addition, community groups showed their less concern over the role of Village Society Empowering Department at the regency level. Based on the acknowledgement of several district heads, the lack of coordination at the level of the community group, the UPST, and the village leader to the subdistrict, was due to the implementation of village autonomy under the Law Number 6 of 2016 concerning the village which reduced the role of subdistricts in the implementation of development at the village level after the adoption of the law. Therefore, some village leaders felt there was no need to coordinate with the subdistrict but directly went to the regent. 4) Supporters of community groups have difficulties in collecting funds from farming groups that have been due. Based on the acknowledgment of one of the staff of the Village Society Empowering Department, the solution was to replace the community group with the local village's actor with the hope the Village Society Empowering Department would be able to raise the Sari Tani fund loan to the farmer group.

\section{Implementation of Sari Tani Program: Political Perspective}

Implementation of the Sari Tani program in the TTU regency involves crossinstitutional and many actors in stages, ranging from district level to village level. The number of actors involved allowed the emergence of interventions in the same way. At the regency level, the beginning of the program implementation involved elite rulers and bureaucrats, in which the political atmosphere always surrounds the decision-making process. In a political perspective, bureaucrats elites involved in the implementation of this program are generally inseparable from such motives; power, income, prestige, security, convenience, loyalty, pride in the work results, and the desire to serve public interest (Festianto, 2013: 128). The actors referred to this are ranging from the relevant regional officers organizations to the village government.

The diversity of the actors interests affects the dynamics of the implementation of this program in the field. In this context, one of the forms of interaction between the decision maker and the implementer is seen in the early stages of the activity, namely the recruitment phase of the PKM conducted by Village Society Empowering Department. This stage is politicized by bureaucratic elites by the way of recommending their own people who apply to join the PKM which makes the recruitment process to be just a form of mere formalities. People who are being recommended by the elite are those who have the same political affiliation or still have family relationships. Working with a systematic political network by formalizing the recruitment process of the community group generated a less optimal accompaniment. This is due to the relatively low capacity of field co-operators who do not correspond to the scientific field specification required in providing assistance to farmer groups. In addition, the proximity factor to the elite of rulers and policyholders is made as a shield by the community group when their performance was evaluated by the district or village leaders. Based on the village leaders' recognition, the community support group is less intense in assisting the village. This phenomenon suggests that related regional officials organization in the monitoring and evaluation process tend to be weak and helpless in the face of strong intervention of political interests, both political and elite bureaucracy. As a result, cross-institutional control functions in stages are not running optimally because they have conflict of the interests between the authorities.

In addition, external cross-institutional coordination also shows the tendency of the emergence of the ego sector resulting in conflict in the field. Weak coordination in assistance to farmer groups carried out by agricultural extension and co-supervisor from Village Society Empowering Department, Agriculture Department, Farm Department, BKP3 and the non-governmental community partners cause frictions between them in 
the field. They claim to each other about the limits of their respective authorities such as those in Oeolo Village and the emergence of social jealousy due to disparity in employment status. The companion of the community group stated in the regional contract in the process of distributing the incentives is always late to three months; this is one form of the less intensive or inadequate facility in the field.

The weak cross-institutional coordination is also seen in the verification of the feasibility of cows purchase by target groups. Purchase of cattle breeds for the business is according to the standard of Department of Animal Husbandry, that is at Rp.4.000.000,00 per cattle. However, in fact, some farmer groups bought beef cattle for Rp.2.000.000,00 per cattle. If the purchase of cattle breeding was according to the standard, in the first year it can be sold at a price of Rp.10.000.000,00 per cattle. With such calculations, ideally, farmers would not have difficulty in returning Sari Tani fund, but the reality said the contrary. Facing such cases, the relevant agencies have not been able to impose sanctions on the farming groups who commit these deviations since there is no regulation of mechanisms and forms of such sanctions in technical guidelines the case above shows the less synergistic of cross-actors and the weakness in identifying the feasibility of cow purchase for breeding.

The model of Sari Tani aid management mechanism applied through a cultural social perspective has indirectly changed the values of collectivity in rural communities. Social cohesiveness as a characteristic of rural communities has been weakening and shifting to individualities values. The distribution of Sari Tani funds is based on the type of business of a farmer group that usually consists of ten members, in which the management is conducted by each member individually. As a result, when the livestock of one member is dead, it becomes the responsibility of the concerned member alone and the other farmer members do not have to share that responsibility. This management model has contributed to creating individualism since its management is collective.

The background of this program cannot be separated from political promises during the campaign, so that there is a tendency for the regime to always claim that the implementation of Sari Tani program has succeed in alleviating poverty in the rural areas and has hit the centers of productive economic activities in the targeted villages. Claims for successful poverty alleviation programs are also supported by data released by the Central Bureau of Statistic of TTU showing a tendency of poverty-reducing in TTU regency.

However, if it further traced, the claims of successful implementation of the program were inversely proportional to the findings in the field showing the amount of the arrears of Sari Tani funds at the target group level until February 2017 which showed a high figure of $62 \%$. In addition, the returning fund is partly coming from business outside the type of business that receives assistance from Sari Tani program (the average community has other farming business). This phenomenon mostly influences on the sustainability and performance of this regent's flagship program. Thus, the success and of the policy are determined by the timely allocation of resources, the integration of the hierarchy between the implementing agencies, and leadership capabilities of the implementing offices (Keban, 2008: 57).

\section{Conclusions}

Political intervention in the implementation of Sari Tani program was conducted gradually. At the district level, it was conducted by the Village Society Empowering Department during the recruitment of community assistant group. Some of the community's associates had proximity to elite rulers or bureaucrats, closeness based on political affiliation, and family ties. This has led to the unoptimal control and monitoring function performed by the institution in the tier to the performance of the community group companion (PKM). While interventions at the village level occur at the community identification stage to determine which one deserve the aids from Sari Tani, where the village leader and the implementing agency of Sari Tani manipulated the data by submitting their families or those who have the same political affiliation with the village elite and the elite authority. This caused some of the Sari Tani's assistances went to to the wrong target. While internally, the Village Society Empowering Department as program coordinator has not been able to apply control instruments and sanction mechanisms related to the performance of the field assistant and to the farmer groups who have not yet paid the aid of Sari Tani. In the end, the magnitude of intervention of actors' political and economic interests involved in 
the implementation of this program has an impact on the unoptimal performance of the Sari Tani program marked by the low rate of return Tani of Rp.13.678.956.150,00 or $38 \%$ of the total funds disbursed amounted to Rp.36.111.518.676,00.

Based on the above conclusions, it can be said that the objectives and targets of the Sari Tani program can be achieved and to improve cross-sectoral coordination, the local government needs to establish a special team. This team will play a role as coordinator in accelerating the development of the agriculture sector which is directly responsible to the Regent. This team is also independent because based on the analysis, the root of the unoptimal problems of the performance of Sari Tani program due to the large intervention of political and economic interest and the weakness of gradual control function.

\section{References}

Bekun, S, Agustinus L. Tiza (2017). Pemberdayaan Masyarakat Pedesaan Melalui Transformasi Nilai-Nilai Kewirausahaan dalam Pelaksanaan Program Desa Mandiri Cinta Petani (Sari Tani) di Kecamatan Insana Kabupaten Timor Tengah Utara, Agrimor, Vol. 2, No. 1, pp. 4-9.

Creswell, J, W. (2010). (translation Achmad Fawaid). "Research Design Pendekatan Kualitatif, Kuantitatif dan Mixed", Yogyakarta: Pustaka Pelajar.

Dima, Y, K. (2016). Evaluasi Pelaksanaan dan Strategi Keberlanjutan Program Padat Karya Pangan di Kabupaten Timor Tengah
Utara, Jurnal Ilmu Administrasi Publik (JIAP), Vol. 2, No. 4, pp. 171-176.

Festianto, D (2013). "Interaksi Politik Birokrat dan Petahana di Timor Tengah Utara (TTU) dalam Pilkada 2010", Thesis. Yogyakarta: Program Pascasarjana Jurusan Politik dan Pemerintahan FISIPOL UGM.

Grindle, M, S. (1980). "Politics and Policy Implementation in the Third World", New Jersey: Princeton University Press.

Keban, J, T. (2008). "Enam Dimensi Administrasi Publik: Konsep, Teori dan Isu", Yogyakarta: Gava Media.

Mahmudi (2010). "Manajemen Kinerja Sektor Publik", Yogkarta: UPP STIM YKPN.

Moleong, L, J. (2001). "Metode Penelitian Kualitatif", Bandung: PT. Remaja Rosdakarya.

Regional Medium Term Development Plan (RPJMD) of North Central Timor Regency for 2010-2015 and 2015-2020. Kefamenanu.

Regulation of the President of the Republic of Indonesia Number 131 Year 2015 on the Determination of Disadvantaged Regions 2015-2019. Jakarta.

Statistic Center Board (2009-2017). North Central Timor In Figures. Kefamenanu.

The Regulation of the Regent of North Central Timor Number 18 of 2013 on Guidelines for Implementation of Sari Tani Program. Kefamenanu.

Yin, R, K. (2002). (translation Mudzakir) "Case Study Research Design and Methods", Jakarta: PT. Raja Grafindo Persada.

Zulfida, I, Akhmad Fauzi, Ernan Rustiadi, Yusman Syaukat (2015). Kinerja Program Nasional Pemberdayaan Masyarakat Mandiri Perdesaan di Kabupaten, Mimbar, Vol. 31, No. 2, pp. 307-318. 